ANDEBET HAILU ASSEFA,

Sant' Anna School of Advanced Studies (Pisa, Italy)

e-mail: andebethailu.assefa@santannapisa.it,ORCID 0000-0001-8698-2364

BELAYNEH TAYE GEDIFEW,

University of Szeged, (Szeged, Hungary)

e-mail: belayneh3415@gmail.com, ORCID0000-0003-1629-136X

\title{
SYMBOLIC VALUES AND IMPLICATIONS OF THE GRAND ETHIOPIAN RENAISSANCE DAM PROJECT IN ETHIOPIAN IDENTITY POLITICS
}

This paper attempts to show how the Grand Ethiopian Renaissance Dam (GERD) 's economic and political gains could help develop a shared outlook to regulate Ethiopia's opposing political trajectories, i.e., the ethnocentric and pan-Ethiopian nationalist camps. Presently, different ethnicbased "in-group and out-group" contrasting political discourses have dominated Ethiopian polity. The paper reviews and exposes relevant philosophical concepts, including "mirror identity", primordial and instrumental conception of ethnicity. Notably, following Anderson's (2006) line of thought, nationalism as a "cultural artefact" and expression of an "imagined community", the paper argues that GERD could serve as a shared symbolic and developmental language to reshape Ethiopian national consciousness and imagination by improving the political and economic domains of the country. Accordingly, the GERD covertly or overtly helps reform the polity's selfrecognition mechanisms and circuitously re-approaches outstanding political differences by inspiring trust-based relations among major political actors. Ethnocentric motivations raise political questions such as secession, the right to linguistic and cultural recognition, economic equality, and political security and representation by using their respective ethnic lines as means of political mobilization. In current Ethiopia, political identities have been practically blended with ethnic identity. In this sense, as diverse ethnic groups exist, political borders sustain among the multiple ethnic-based nationalists and between pan-Ethiopian and ethnocentric actors. Thus, a comprehensive dialogue and constructive political cross-fertilization are required between various political actors, horizontally and vertically, among ethnocentric nationalists and the pan-Ethiopian advocates. In Ethiopia, the realization of internal political consensus requires an instantaneous remedial mechanism. Accordingly, the politically drawn antithetical ethnic demarcations and occasionally fabricated historical narratives have undeniably pushed politics into unfavourable conditions. That is why, as the paper maintains that developmental projects such as the GERD would have pertinent economic and political mechanisms to developing a national sentiment, which in turn symbolically facilitate national consensus among the major political actors. Hence, borrowing Fukuyama's (2018) notion of "creedal national identity", one could resonate those developmental projects can help realize symbolic worth by constructively enabling citizens to recognize their countries' foundational ideals and elevating common factors. In terms of scope, the present paper does not examine the GERD project's external geopolitical and legal concerns, although these topics are worth examining for further investigations.

Key word: Ethnicity, Ethiopia, Ethnic federalism, GERD, Developmental Language, Identity Politics.

\section{Introduction}

Identity politics has been one of the political organizing mechanism and expression of various political communities. According to Fukuyama (2018), recently, politics is essentially associated with identity and populist nationalism. In this sense, democratic societies have promoted identity and differences instead of creating broader economic equality. Accordingly, in the world, the recent development of identity politics does not pay much attention to economic equality. This condition elevates identity politics while it ignores the marginalized and poor fellow citizens. The struggle for identity politics, resentment concerning the lost "dignity" or invisibility has economic roots leading to political discords and instability. It follows that realizing an integrative national identity that considers the de facto diversity of liberal societies is essential to maintain political stability and identity recognition (Fukuyama, 2018).

Similarly, developing countries like Ethiopia that have been exercising identity politics, need to integrate and build the educational, democratic, and institutional aspects to address identity and recognition challenges (Gedifew, 2020). Accordingly, one can plausibly argue that developmental projects such as the GERD would provide crucial economic solutions because they have symbolic significance to rethink national unity. In other 
words, GERD and other national projects covertly or overtly help reform the polity's self-recognition mechanisms and circuitously re-approaches outstanding political differences by inspiring trust-based relations among major political actors and the public. Developmental projects such as GERD help foster symbolic values and enable citizens to recognize themselves in shared fundamental unification factors. Thus, such projects could serve as an expression of "creedal national identity" (Fukuyama 2018:106).

Ethiopia's attempt to build a hydroelectric power project over the Blue Nile River has a long historical, developmental, and political background. In 1964, the last emperor of Ethiopia, Emperor Haile Selassie (19301974), had thought to build a hydroelectric and irrigation dam over the Blue Nile River (Baker, 2016). Although the emperor was a historically and politically controversial figure, he sought to modernize the country by introducing various new projects, including building hydroelectric dam projects over the Blue Nile. Similarly, the SocialistLeninist Derg regime, led by Colonel Mengistu Hailemariam (1974-1991), also committed to building developmental projects over the Blue Nile basin. Mengistu's regime, for instance, initiated an agroindustrial project of Tana-Beles, near the largest Lake in the country, Lake Tana (Carr, 2017:27). Lake Tana is the source and contributor of around $7 \%$ of the Blue Nile's water flow (Yohannes, 2008:86).

The Grand Ethiopian Renaissance Dam (GERD), however, is a mega hydroelectric power project. Since 2011, the project has been under construction over the Blue Nile, which accounts for around $85 \%$ of the Nile River's overall flow, the world's longest mighty river. In 2021, GERD's construction is completed by more than 79\% (Egypt independent, 2021). After fully accomplished, the project will generate $6,000 \mathrm{MW}$ (International Hydropower Association, 2020). The project is being constructed approximately $15 \mathrm{~km}$ away from the Ethio-Sudan border (Yihdego et al., 2017) in Guba of Benishagul-Gumuz regional state, one of the ten ethnically and linguistically organized regional administrative sub-states of Ethiopia. As the first round of filling has been completed, GERD's reservoir currently contains $4.9 \mathrm{bcm}$ of water (Abdelhadi, 2020).

Despite internal and external political hurdles, the Ethiopian government and people have continued constructing this hydroelectric power project. Furthermore, Ethiopians expect that the GERD will profoundly improve the country's various sectors, including the economic and political domains. After completing the GERD project, the country will realize the largest hydroelectric power plant on the African continent to improve the infrastructural and energy integration among the region's countries. When it is completed, the project creates a reservoir capacity of about 73bcm (Abtew \& Dessu, 2019: 99). Notably, Ethiopia's total hydropower generation capacity is estimated at 45,000MW (International Hydropower Association, 2020), the second-largest potential in the African continent next to the Democratic Republic of Congo (King \& Block, 2014: 234).

This paper attempts to analyze GERD's symbolic implications in interethnic and Pan-Ethiopian nationalist political courses of contemporary Ethiopia. The project is largely valuable to nurture the domestic politics of Ethiopia. Thus, GERD's fruition could serve as a critical trajectory in promoting political unanimity in the ethnically polar- ised Ethiopian politics. Hence, the paper underlines that GERD has practical implications in Ethiopia, although its implementation will be inevitably challenged by global problems such as climate change and regional concerns.

Historically, it is true that the share of Blue Nile's water resources has instigated external concerns, particularly by the two downstream countries- Egypt and Sudan. However, it is not the intent of the current paper to address these concerns and controversies, although the authors believe that these issues are open to further investigation. In any scenario, they need peaceful resolution under trustful and cooperative frameworks, which is necessary to realize a win-win solution, and to comprehensively address the intergenerational concerns related to the Blue Nile water resources distribution.

\section{Material and Methods of the Study}

This article employs a qualitative research design following a phenomenological hermeneutic approach of research. The hermeneutic approach is a research method significant to comprehend natural and social phenomena using the interpretation of symbols, texts, and human experiences as a mechanism. As Gadamer argues, hermeneutics as a techne of preaching, interpreting other languages, explaining, and explicating texts is the art of understanding and meaning making (See Palmer 2007). Likewise, David Ricoeur describes hermeneutics as a theory of operation of understanding related to the interpretation of texts and symbols that we have in the language and our experience. Interpretation, Ricoeur claims, consists of deciphering the hidden meaning in the apparent meaning and unfolding the meaning implied in the literal meaning. This deciphering of meaning or interpretation is called hermeneutics. For Ricoeur, hermeneutics is part of self-understanding and understanding the essence of other things mediated by reflection and understanding (Ricoeur cited in Itao, 2010).

Accordingly, critical hermeneutics is found useful in this research to approach GERD's symbolic significance on the landscape of contemporary Ethiopian politics. The study has used research articles, books, documents, government statements, news, and other documented and undocumented sources relevant to the topic as a source of data. As the gist of interpretation, the paper uses relevant philosophical concepts, including "mirror identity," primordial and instrumental conception of ethnicity. Notably, following Anderson's (2006) line of thought, nationalism as a "cultural artefact" and expression of an "imagined community," the paper tries to identify a shared symbolic significance GERD could offer to reshape Ethiopian national consciousness and imagination. Following the conceptual framework of Fukuyama's (2018) notion of "creedal national identity", the article also interprets the symbolic worth of GERD for citizens to recognize their countries' foundational ideals and elevating common factors.

\section{Result and Discussions}

Fault-lines of Ethnocentric Politics in Ethiopia. Since adopting the currently functioning constitution on 8 December 1994, Ethiopia's federal structure has officially vowed ethnic and linguistic identity as a leading political rule. The constitution of the Federal Democratic Republic of Ethiopia boldly grants ethnic-based regional administrative structures. Similarly, the constitution categorically 
provides every nation, nationality, and people the right to self-determination and even secession. This provision prioritizes ethnic-based collective rights, undermining individuals' political recognition and rights, especially those who are not originally members of the ethnic group that appropriated the region. One can argue that the collective ethnic-driven grievances have been entertained mainly through gaining political power, political offices, land, wealth, and other resources. This political culture undermines a reliable meritocratic political and economic competition.

Among other things, political identity essentially designates "a set of values, principles, memories, and symbols" (Cerutti, 2017:28-29). However, sometimes, these conceptual elements of political identities could further manifest political divisions among ethnic groups in Ethiopia. For example, mainly because of political, ethnic contests, there are considerable disparities among ethnocentric nationalists and pan-Ethiopian nationalists about historical and political legacies of heroes, victories, and leaders. Ethnic-identity politics exacerbates the diverging narratives among the groups. Meaningful and inclusive mechanisms could approach to address such divergences. As a developmental flagship project, GERD could regulate the polarised ethnopolitical trajectories and facilitate political consensus.

Ethiopia has indeed been under political tensions, mainly due to diverged ethnic interests. Some of these tensions are grounded on reasonable grievances, whereas most of them result from the elites' unreliable political motivations. Accordingly, the ethnic-based exclusionary realities have characterized polity as one of the world's ten most conflict-prone nations (International Crisis Group, 2019). Nonetheless, "the idea of a nation based on an exclusive characteristic is prone to all kinds of derailments, one of which being the dangerous slide from patriotism to ethnonationalism" (Messay, 2020).

Various forms of ethnic immoderation aggravate Ethiopia's unfolding negative political situations. Innocent groups and individuals have been suffering from political hostilities, mainly sourced from the primordial and instrumental accounts of ethnic identity politics. Notably, primordialism considers ethnicity as an inborn and fixed identity. Whereas for instrumentalists, ethnicity is a means for some other end, including political end (Joireman, 2003:35). In Ethiopia, ethnicity has become a means of political mobilization and dominance. Politically, ethnic narratives serve as an apparatus of subjugation against others. The contest for political power and representations covertly or overtly presumes the collectives' interest. At the same time, individuals' interests and justifications of party policies and programs become secondary. These kinds of political courses have recurrently produced opposing power pursuits, particularly among the ethnic elites. Thus, the realization of reasonable political harmony and consensus is a central issue in Ethiopia.

As indicated elsewhere, EPRDF was an ethnic-based political coalition that functioned mainly under the influence of TPLF, the Tigray regional party that ruled Ethiopia dominantly for around three decades. Before gaining power, TPLF had an effective local structure and foreign relation, which also helped the Party arrange and design institutions after the war and constitutionally introduced an ethnic-based political structure in Ethiopia (Lyons, 2019: 6 and 7). Since the Party held power, TPLF led EPRDF dominated important political, economic, and military leadership offices of the Ethiopian state. Some manifests of ethnic driven domination have been noticeable in the internal political structure of EPRDF itself. For instance, the coalition's central committee appointments indicated a considerable degree of asymmetry in the advantage of TPLF since 1991 (Lyons, 2019:147). For a significant number of years, until mid-2010, TPLF asymmetrically dominated the central committee members of EPRDF, which even overbalanced the remaining constituent parties, including the Amhara National Democratic Movement (ANDM) and Oromo People's Democratic Organization (OPDO). ANDM and OPDO represented around $60 \%$ of the total Ethiopian population.

From 2001 to 2013, ANDM had 61 members while OPDO had 63 members, and SEPDM had 69 members, whereas TPLF had 45 members in the central committee of the EPRDF. In Ethiopia, the two largest ethnic groups are the Oromos (34.4\%) and the Amhara (27\%) (World Population Review, 2021). During the indicated period, these ethnic groups were represented by 63 and 61 members in the central committee of the ruling coalition. In contrast, the 5 million Tigrayans were, on average, represented by 45 members (Lyons, 2019:147). In other words, in the indicated period, compared to the remaining coalition parties of EPRDF, on average, 1 TPLF member of the central committee used to represent around 95,877 people of the Tigray region. Moreover, 1 SEPDM represented 224,515 inhabitants in Southern Nation Nationalities and Peoples' Region (SNNPR); 1 ANDM member represented 273,239 inhabitants of Amhara Region, and the number becomes 502,935 in the OPDO of Oromia (Lyons, 2019:147-149). These kinds of asymmetric distribution privileged the TPLF in the leadership and offices of the state structure that continued until the dissolution of TPLF/EPRDF and succeeded by the Prosperity Party (PP). Undeniably, after 2015, the dominance of TPLF in the EPRDF had been in some way reduced as constituent parties' leadership joined based on "seniority and experience" (Lyons, 2019:150).

Notably, before the establishment of PP, the remaining ethnically defined regions of Ethiopia, including Afar Regional State, Gambela Regional State, the Somali Regional State, Benishangul-Gumuz Regional state, and Hareri Region, had no significant place in the central committee and council of EPRDF. These regions had no notable involvement in the essential matters and decision making in the coalition of EPRDF and shaping the state structure at the national level. Moreover, the EPRDF recognize some of them as Agar Dirigits or supportive parties.

PM Abiy Ahmed's speech to the Parliament underlined that before the so-called reform under his leadership, the defense force or military offices and commanders were highly dominated by Tigrayans. According to his speech, before his Party, i.e., PP reformed the leadership structure, the military's top leadership, including Generals and Major Generals, about 55 per cent were officers from the Tigray region. Notably, the PM stressed that the mechanized Brigade of the defense force was dominated $100 \%$ by officers from Tigray, as this Brigade mainly 
required specialized skills and experience, and officers from TPLF remained relatively well-experienced. However, even after the reform, as PM Abiy stated, it was difficult to change the status quo of the Mechanized Brigade. At the time of Abiy's speech, his government reduced this number to 50 percent, that it was not possible to achieve more than 50 percent. Notably, it was also stated that officers from Tigray controlled the Infantry Brigade and held for around $80 \%$ of its leadership. In comparison, generally, they controlled the mechanized Brigade in $85 \%$, and around $50 \%$ of the staff and training division was dominated by officers from the Tigray region (Abiy, 2020: 92-93). Therefore, one can generically claim that there is asymmetric severe in Ethiopia's ethnopolitical state structure both in terms of controlling soft and hard power.

For many Ethiopians, the Blue Nile or river Abbay designates a symbol of sovereignty and prosperity. That is why, regardless of their ethnic and political differences, Ethiopians are financially contributing to the project; and they consider GERD as a symbol of pride (International Crisis Group, 2020). Thus, they anticipate the GERD is primarily a developmental project that can gradually help unchain a country from multifaceted internal economic and political problems. The share and proper utilization of Blue Nile water resources would highly facilitate the country's development and lessen poverty-related challenges, including food insecurity and energy scarcity. Some scholars, for instance, concede that Ethiopia's "structural food insecurity" problems originate from the recurrent ethnocentric and fixed dominance of the Amhara and Tigrayan elites in politics (Yohannes, 2008:88). Arguably, however, political leaders from different ethnic groups, including the Amhara, Oromo, Tigre, Gurage, and others, have contributed to the current Ethiopian-state realities.

Political communities and regional governments have been organized based on ethnic and linguistic identity divisions - which have produced opposing political arrangements. However, borrowing Cerruti's (2017:29) concept of "mirror-identities", one could argue that various kinds of opposing ethnic group mirrors have already been developed and caused serious political demarcations in Ethiopia. In turn, this condition has stimulated conflicting ethnic-centred outlooks and political goals. Consequently, in Ethiopia's current context, these trajectories have exacerbated political divergence instead of promoting political convergence among elites of ethnic groups.

Mainly because of ethnic-based political organizations, the country has produced multiple seemingly irreconcilable "self-identification" among groups (Cerutti, 2017:29). Thus, the present ethnic federalism of Ethiopia exhibits a feebly knotted and sceptic ethnopolitical system among various groups. However, these kinds of political crises result from the manipulated and distorted conception of ethnicity, indicating ethnicity as an ultimate exclusionary political path, not originated from the recognition of ethnic groups and their respective identities.

Ethnocentric Political Contentions, Strains, and Exclusionary Identity Tensions. In 2018, around 2.9 million people were domestically displaced mainly because of "ethnically motivated inter-communal conflicts", which put Ethiopia as a leading country globally in the domestic displacement of citizens (Wilson, 2019). Similarly, it has been estimated that in March 2019, approximately 3 million individuals were internally displaced in Ethiopia, mainly because of conflict (International Organization for Migration, 2020). For instance, according to the Displacement Tracking Matrix of the United Nations Office for Humanitarian Affairs (2018), at least 1,073,7642 people were displaced due to the border conflict between the Oromia and Ethiopian-Somali regions. Moreover, around 15,000 people were expelled from Addis Ababa's border areas, mainly because of politically motivated inter-communal violence (Human Rights Watch, 2019). More than 100 people have been killed in the country's Western region, Metekel Zone of Benishangul Gumuz (The Guardian, 2020), to mention some of the recurrent ethnic-based incidents, insurgencies, and killings in the area.

Similarly, in the West Welega Zone of the Oromia region, at least 54 innocent civilian ethnic Amhara's has been killed and many displaced by the Oromo Liberation Army (OLA) members (Sky News, 2020). Most importantly, in Ethiopia's Tigray, because of the conflict between the ousted TPLF and the Ethiopian National Defense Force (ENDF), more than 50,000 people fled to Sudan. More than 100,000 people were internally displaced even before the conflict (UNHCR, 2020). However, these ethnic-based adverse incidents and consequences of killings, acts of violence, and conflicts are by no means an exhaustive description of ethnically motivated political tragedies in Ethiopia as the political tension is a growing reality. Accordingly, ethnic-based conflicts and killings have already become common problems in many parts of the Ethiopian polity.

After the fall of Derg regime (1974-1991), Ethiopia has conducted five general elections. However, none of these elections has nurtured a sustainable democratic culture; for almost the past three decades, a single political party called Ethiopian People's Revolutionary Democratic Party (EPRDF) had dominated both the upper and the lower houses. Nevertheless, on 1 December 2019, EPRDF was dissolved and reshaped to form the current ruling political party known as the Prosperity Party (PP). The PP is composed initially of the political parties that have governed the regional states under the parasol of EPRDF. This party had been highly controlled by the Tigray People's Liberation Front (TPLF). Yet, TPLF refused the formation of PP and ousted Tigray's capital, Mekele.

Citing the Covid-19 pandemic outbreak, the Ethiopian government has delayed the sixth general election, which was supposed to take place in August 2020 (Marks \& Dahir, 2020). Some opposition political parties have recurrently rejected the postponement asserting that the incumbent is using the pandemic to justify its unconstitutional extension of tenure. Notably, based on the country's functional constitution, the incumbent's tenure-term ended on 30 September 2020. Nevertheless, PP was granted an extension of tenure by the parliament (Aljazeera, 2020), even though the tenure extension has been the immediate cause of difference among the main political actors, particularly between ethnocentric nationalists and pan-Ethiopian camps. Notably, the current parliament is dominated by the PP members. Accordingly, at 
the time of this writing, Prime Minister Abiy Ahmed's current political leadership in PP took political office, not by a free and fair electoral process. Instead, PP is the political output of a former incumbent's reformed status quo, practically emerged due to the people's uprisings and protests the former TPLF/EPRDF's authoritarian rule.

Despite internal political controversies and conflict, especially between the central government and TPLF, Ethiopia has planned to conduct the sixth general election in June 2021. Concerning the sixth general election's postponement, major opposition parties have not adversely reacted. However, they vehemently opposed the incumbent's tenure extension process. Notably, the constitution's proclamation on tenure extension is open for controversial interpretation, which has furthered the tensions between the incumbent and some opposition political parties-viewing the incumbent's tenure extension as a unilateral and unconstitutional decision. Instead, they propose that the decision needs a political dialogue between the incumbent and all opposition political actors.

The legacies of TPLF are still active and prevailed in the post-EPRDF era. However, TPLF was a regional party that ruled the Tigray region since it seized political power from the Derg regime. The ethnic-Tigrayans account for around $6.1 \%$ of the country's population (World Population Review, 2020). TPLF rejected the sixth general election's postponement and the extension of PP's tenure. Despite the central government's recurrent warnings, however, Tigray Region conducted a regional election and proclaimed the win of all the seats for the regional legislature house (Melesse, 2020), although the PP's federal government outlawed the election. This kind of unilateral political election could indeed impose a "strain on the country's fragile unity" (CGTN Africa, 2020).

Accordingly, the political tension between the central government led by Prime Minister Abiy Ahmed and TPLF's regional group escalated and instigated a sharp political tension, leading to military conflict between them since 4 November 2020. The central government's 'law enforcement operation', as described by Prime minister Abiy, started after the "Tigrayan attack and takeover of federal military units in the region" (Malley, 2020). Notably, on 9 November 2020, in Mai-Kadra, "likely hundreds" of people were gruesomely killed (Amnesty International, 2020) during this military conflict, and many thousands displaced. Hence, this suggests that the upcoming general election will undertake in a politically unstable condition.

The Ethiopian polity has already experienced different forms of political discords deepened by establishing an ethnic-based constitutional system. What is more, in this kind of nation, ethnically formed identities it is difficult peacefully open to each other for enlightened political dialogues and practical changes. On the contrary, ethnic politics induces a highly restricted political identity "diffusion" among groups. Accordingly, the diverse political "wall identities" possibly developed into forces of "separation, exclusion or enmity" (Cerruti, 2017: 29). Demonstrably these kinds of separatist political courses are increasing in the Ethiopian political conditions, which is seriously challenging the unity of the country.

Why has that ethnonationalism aggressively developed as dominant political stamina in Ethiopia? The an- swer to this question is seemingly complicated and goes contentious. However, thinkers like Yohannes (2008) claimed that $35 \%$ of elites that dominated the Ethiopian power politics came from the Amhara and Tigray ethnicelite groups (p.97-98). In contrast, the remaining ethnic groups have been marginalized. Thus, ethnic driven political grievance and actual conflicts have historically entrenched reasons originating from ethnic marginalization and inequality. However, the marginalization thesis needs to situate in the proper and rational historical balance.

It is essential to remember that the current Ethiopian polity is also the result of a dialectical past. A search for ethnic political immunity from the past's historical involvement in the name of ethnic marginalization does not justify the selective overemphasis and claims against the two ethnic groups. Instead, the elite-driven politicaleconomic system comprised mixed and pluralistic involvement, including the Amhara, the Oromo, Tigre, Gurage, Sidama and Wolayita, to mention some. Similarly, in terms of economy, one can assess a reasonably comparable but low economic level across the country's ethnically divided regions. Categorically proclaiming that one or two ethnic groups repress the remaining others would be an inaccurate expression of historical and political realities. In effect, it leads to political delusion, which restricts inclusive dialogues among the polarised political groups.

Progressively managing ethnic politics would be an essential move to realize pragmatic and comprehensive solidarity in Ethiopia. However, as ethnopolitical grievances have widely established deep-rooted political antagonisms, it would be impractical to entirely rule out ethnicity from Ethiopian politics, at least in the country's current situation. Nevertheless, the antagonistic and destructive ethnopolitical trajectories need to be dissolved as swiftly as possible. In this sense, developmental projects like GERD would have constructive and symbolic relevance by elevating solidarity factors, as they could gradually reshape the polity's economic and political dimensions. Accordingly, for Ethiopians, GERD would be characterized as a modern symbolic apparatus perceived as a sign of unity, which has brought them to realize the historical and natural pursuit of using the Blue Nile water resources under cooperative frameworks. The realisation of the GERD project would strongly foster the integration of economic, political, and cultural aspects of the Ethiopian state.

Encouraging individuals and groups to a "homogeneous political culture is indeed essential for the realization of [sustainable] political identity" (Cerutti, 2017:29). Nonetheless, practically Ethiopia is the land of heterogeneous and diverse ethnic groups. In this sense, setting a separation between political identity and cultural/social identity is challenging. Nonethelss, diversity is tension-prone and suggests the need for ethnic recognition and quenching elitists' power-hunger would help realize civic nationalism and multicultural integration in Ethiopia (Abbay, 2004: 613-614). However, ethnopolitical elitists' powersatisfaction could not generate sustainably peaceful political reality; instead, it mainly needs a bottom-up strategy to deal with relevant ethnic concerns.

Since some political discords result from the distorted ethnic political system, their solution requires an inclusive 
and pragmatic approach. Accordingly, political actors need to work on political healing and structural changes, including constitutional amendment and better parliamentary democratic practice. The country inherently requires strengthening state nationalist movements - the move from a plain ethnopolitical nationalism to a civic nationalist outlook. Notably, "nationalist sentiment in support of the state-what we might otherwise call civic nationalism - is tremendously important for the well-being of the state" (Joireman, 2003: 46). Accordingly, in Ethiopia, developmental projects would mean mechanisms that possibly reshape the broader nationalistic outlooks by indirectly regulating the polity's opposing discourses.

Can GERD serve as an economic springboard and political harmony in Ethiopia? How? According to the World Bank (2019), Ethiopia's GDP was ranked 64th globally at $\$ 96.10 \mathrm{bn}$, and the per capita income was $\$ 850$. Furthermore, Ethiopia has been considered one of Africa's fastest-growing economies, particularly with an average of $9.9 \%$ a year from 2007/08 to 2017/18 (World Bank, 2019). Despite these changes, Ethiopia is still listed under the low-income countries. Notably, Ethiopia's population is also estimated at 112 million, making it the second-most populous country in Africa (World Bank, 2019).

As a lower-income country, Ethiopians have been negatively affected by many economic related challenges. For instance, more than $78.7 \%$ of Ethiopians live in rural areas (World Bank, 2020). They have limited access to necessary infrastructures and services such as education, health, electricity, and roads. Among other aspects, in 2018 , only $32.7 \%$ of the country's rural population had access to electricity; and only around $45 \%$ of the total population had access to electric power (World Bank, 2020). Similarly, about $70 \%$ of Ethiopia's housing components require entire replacement (Habitat for Humanity, 2019). In 2016, around $24 \%$ of Ethiopians lived below the national poverty line (World Bank, 2020). Recently, the country has been adversely challenged by the worst locust invasion, the COVID-19 pandemic, political disturbance, inadequate competitiveness, and a weak private sector (World Bank, 2020). Accordingly, generating visible economic benefits from the natural resources would be a primary shared responsibility instead of devoting to treacherous and retrospective interethnic accusations. Notably, there are no ready-made models to retain political consensus, mainly where ethnically polarised beliefs largely influence politics.

The GERD could reduce ethnic-based political strains by meaningfully lessening poverty-related difficulties because poverty is the main reason that intensifies extreme ethnic-based nationalisms in Ethiopia. Here, it is noteworthy that "ethnicity is a kind of manifestation of identity, whereas nationalism is a politicized shared identity" (Joireman, 2003: 9). Commonly, the diverse ethnic composition and realities could be regarded as valuable and cohesive grounds for the polity when it is appropriately managed. However, when one considers ethnic identity as a means and yardstick of politics, it would inexorably lead to political delusion and a distorted conception of nationalism that draws antagonistic boundaries. The country needs to realise a just and democratic political system by balancing and compromising the reasonable political and economic questions. Otherwise, borrowing
Joireman's (2003: 22) idea of the "in-group versus outgroup" asymmetric conditions, one can argue that the Ethiopian long history of statehood would be adversely affected.

Creating multi-complex political and social drifts between groups would inevitably contest the polity's prospects internally. As indicated elsewhere, Ethiopia's ethnic politics mainly involves the primordial understanding of ethnicity by considering ethnicity as a static and innate identity expression. It also holds the instrumentalist component since ethnic mobilization could serve as a tool to achieve political goals (Joireman, 2003: 35). These understandings and absolute ethnic injection in the Ethiopian political vein have exacerbated interethnic tension and disputes.

In Ethiopia's 6th general election, held on 21 June 2021 , more than 40 political parties have officially competed for the poll $(B B C, 2021)$. Most of these political parties are organized under ethnic identities. In effect, political parties in Ethiopia's ethnic federalism are political outputs that mostly imply exclusionary and self-bounded ethnic dichotomies; instead of promoting tolerant coexistence among diverse ethnic groups. Furthermore, one could argue that these political parties use ethnicity as the main instrument and a primordial concept to achieve their political objectives. Usually, based on ethnic grounds, they raise political questions such as secession, the right to linguistic and cultural recognition, economic equality, and political security and representation. Occasionally, in the Ethiopian context, ethnic political mobilization essentially depends on the counter-discourses of the other, which viciously polarize their political positions.

Since the Ethiopian polity is heterogeneous and socially blended, it would be implausible to secede and achieve an ethnic-grounded new sovereign state peacefully. It is believed that such an attempt would politically seem promising for ethnocentric camps, but its pragmatic functionality is beyond scepticism and highly complex. Accordingly, political antagonisms have been expressed mainly through ethnocentric movements in response to pan-Ethiopian outlooks. Indeed, the drawn ethnic demarcation and the narratives have pushed Ethiopian domestic politics to the edges. But it is true that the gradual move to civic nationalism mainly requires the subjective feeling of individuals to become members of the polity (Joireman, 2003: 25-26). Here, civic nationalism assumes an individual's enlightened rational and psychological closeness, particularly to her/his country, instead of adopting an ethnocentric structure of political identity. Thus, "identification with the state has superseded ethnicity in civic nationalism" (Joireman, 2003: 25-26). Indeed, the Ethiopian polity requires a gradual shift to the political culture of civic nationalism that transends ethnic the mere nationalism.

GERD's economic gains will have a vital contribution to shaping and directing groups under a pan-Ethiopian national consensus by discursively informing the country's political and economic realms. However, the challenge is how the polity could re-generate the consensus, given that ethnopolitical divisions have deep-rooted implications? It would be essential to fostering a generic political model or system to curtail the multi-antithetical political divisions of diverse ethnic groups. In this respect, alt- 
hough the GERD is not an inherently politicalreplacement model, it would serve as a symbolic common ground of consensus.

As stated elsewhere, Ethiopia is indeed in an unfortunate economic situation, including the severe problems of "recurrent famine and food insecurity" (Yohannes, 2008: 99). Thus, improving citizens' quality of life could set an essential step for the practical realization of State-centred civic nationalism. Accordingly, the mega-developmental projects, the GERD, will generate meaningful economic integration and revitalize the pan-Ethiopian nationalist mindset. Ultimately, the GERD's fruition will economically benefit Ethiopian citizens as individuals and a group, immensely, and the region at large. Furthermore, the fair economic distribution of its benefits could raise people's trust in the state's political and economic system, deepening inter-ethnic bonds, too. Like Abbink (2011) indicated, as development changes society, "the benefits and pitfalls" of ethnic-based federalism would become a less critical factor.

GERD's multifaceted gains emblematically improve democratic culture and facilitate a relatively better political representation of individual and group interests. Among other things, GERD's economic benefits improve the living standards of citizens by promoting business relations, infrastructural connection, and industrial establishments. Similarly, the gains of the project help reduce economic problems by improving energy distribution and raising the industrial sector Thus, it enables citizens to meet their political and developmental aspirations facilitated by the people's will and the government's institutional channels. Thus, it could fortify the Ethiopian state by constructively but indirectly nurturing political and economic policy domains. In this sense, the project is the first in its economic size; and it has already stimulated shared psychological solidarity among Ethiopians.

Broadly, GERD has symbolic significance serving as a model of political deliberation between political elites having divergent views and the public to come to a consensus on national ideals. This symbolic significance can be captured from three aspects that GERD could play in building national consciousness. The first aspect is connected to the economic benefit GERD would bring to Ethiopia after its completion. Indeed, the GERD will be vital for energy self-sufficiency, which is the key component for food production, economic development, and poverty reduction in Ethiopia and the Nile Basin (Abdelhady et al., 2015). In fact, in other parts of the world, huge dams such as Aswan Dam in Egypt, Rogun Dam in Tajikistan (Menga, 2015), and Marathon Dam in Greek (Kaika, 2006) and similar other projects serve as an iconographic and symbolic function for modernity and renaissance. Political leaders and elites use these projects as symbols to recollect the greatness of the past and build national consciousness. Equally, from its start in 2011, the GERD has become a symbol of Ethiopian nationalism, which "re-written the Nile Basin's hydro political map" (Abdelhady et al., 2015) and aspiration to bring Ethiopia a renaissance. As we highlighted earlier in this paper, the underlying reason behind identity-based conflict in Ethiopian politics is the economy. In this regard, the economic utility of GERD would have a symbolic function to resonates well with the developmental discourse and broader ideas of nation-building.

The second function of GERD on the Ethiopian political landscape is related to foreign policy matter. The GERD practically stimulated the state's claim for distributive justice concerning the share of Blue Nile water resources utilization. Notably, the Nile Basin's downstream countries have secured the lion's share of the Nile waters that accounts for $84 \mathrm{bcm}$. For instance, in the 1959 agreement, where Ethiopia was not a signatory, Egypt managed to secure $55.5 \mathrm{bcm}$, and Sudan's share was $18.5 \mathrm{bcm}$, and the remaining amount left for a loss of evaporation (Swain, 1997). To maintain this allocation, Egypt successfully limited projects from being constructed over the Blue Nile. As a result, Ethiopia could not receive direct financial support from international financial institutions to build a mega project over the Blue Nile Basin. Despite these hurdles, in 2017, China has financed $\$ 1$ bn and built a high energy transmission line for the project (Abtew \& Dessu 2019:161-67). This friend/enemy distinction plays a significant role in Ethiopian domestic leadership to gather people who support the dam as patriots. In fact, on the Ethiopian side, the Ethiopian leadership presented the dam as a foreign policy matter, targeting Ethiopian nationals regardless of national borders or regional boundaries, serving as a symbol to redefine patriotism vis-à-vis other enemies. Hence, in a setting deeply marked by the historical rivalry between Ethiopia and Egypt, the GERD has a geopolitical significance, facilitating the ethnically fractured political landscape into unity.

Thirdly, political leaders use major dams as a symbol and a propaganda tool to gain political acceptance and reinforce a sense of national identity and patriotism. For instance, the Tajik government in Tajikistan use the Rogun Dam as a propaganda tool to frame the dam as a nationally cohesive and patriotic project (Menga, 2015). Likewise, the Ethiopian government uses GERD as an ideological and propaganda tool to forge national consciousness and build imagined nationality. Furthermore, the Ethiopian government is making the dam construction framed as a matter of national pride, the way to prosperity the resurrection of greatness. These days, the dam's completion is propagated as a matter of life and death for every Ethiopians. Furthermore, GERD is promulgated as one of the largest projects in Africa, and its completion is considered an image of prosperity, success and renaissance to Ethiopia and Africa. Such an image and propaganda can create and strengthen a nationalistic discourse significant for further dialogues among political elites and build fundamental national ideals within the public. Furthermore, hydraulic infrastructural project can exemplify "how the permanent change by human work can create new political spaces and reconfigure the way in which we negotiate and imagine the extent our space of appearance" (Menga, 2017).

Millions of Ethiopians fund the project by buying bonds from the Development Bank of Ethiopia, getting loans from Ethiopian Banks, contributing their salaries, and partaking in musical and athletic performances organized for the project's fundraising. In this sense, the "direct financial contribution of citizens translates to patriotism and political currency to Ethiopia's ruling party" (Abtew \& Dessu, 2019:68). Accordingly, GERD could 
serve as a means of psychological or symbolic expression of solidarity to the Ethiopian state. In this sense, the individual's feeling about the state typically implies a strong sense of civic nationalism (Joireman, 2003: 46-47). Notably, such a close relationship with the state could foster state legitimacy (Cerutti, 2017:28). GERD would help to facilitate a common interest and enlightened consciousness of nationalism in Ethiopia.

As previously noted, Ethiopia's ethnic-based federalism has already exhibited asymmetric recognition of citizens. It has encouraged the hierarchical political recognition of individual citizens and groups across the country's regions, which implies a high level of unbalanced relations between individual interests and communities. On top of that, Ethiopia is endowed with diverse ethnic groups, cultures, languages, and religions (Alem, 2005: 318-321). Accordingly, ethnic fault lines have continued to spread unless transcending political and economic grounds could be introduced, such as in this sense the GERD. As the political identity could signify the "wish-or the duty one feels to become" (Cerutti, 2017: 31). Similarly, the GERD alters the conception of political identity and inspires foreseeable enlightened inclusive changes. Hence, the project's gains can progressively reduce ethnically extreme and multiple dichotomies of the We and the Other by nurturing grounds of collectively shared Will among groups because symbols are essential to discover "cohesion and collective expression" (Cerutti, 2017: 31).

The GERD is neither the origin nor the end of the Ethiopian political identity formation. Nevertheless, its future economic and political benefits would significantly help to restrain the negative extreme nationalist outlooks. In this spirit, the GERD could provide a vital foundation for re-expressing the Ethiopian political community as a symbolic national self-identification apparatus, reshaping the self-recognition mechanisms to peacefully deal with striking differences inspiring economic and political trust among the people.

As previously noted, in current Ethiopia, political identities are practically blended with ethnic identity. In this sense, as diverse ethnic groups exist, political borders sustain among the multiple ethnic-based nationalists and between pan-Ethiopian and ethnocentric actors. Thus, a comprehensive and inclusive dialogue is essentially required between the political actors, horizontally and vertically, i.e., among ethnocentric nationalists and the panEthiopian advocates. These nationalistic versions are not naturally implanted outlooks; instead, they are culturally and socially constructed. Accordingly, as Anderson (2006:4-5) rightly argued, nationalism is a "cultural artefact" that looks like an "imagined community". Similarly, the GERD upholds the country's shared social, political, and economic realms by serving as a developmental language of the Ethiopian political community.

\section{Conclusions}

The paper sought to explain GERD's possible symbolic relevance in shaping Ethiopia's politics and economy in various ways, mainly by indirectly entertaining an enlightened national consciousness among the polity's main political actors. Accordingly, GERD's fruition and its associated changes will provide essential grounds and conditions for the polity's solidarity, which ethnically sharpened political strains have characterized. Consequently, GERD's gains will be critical to balance ethnocentric and pan-Ethiopian political camps' outlooks and look for intermediate political resolutions. Accordinlgy, Ethiopia's political culture could gradually develop from narrow ethnic-centred nationalism towards an inclusive civic nationalistic framework. In this sense, it can symbolize and develop a mutually shared psychological consensus. Indirectly, GERD would facilitate dialogues by addressing the country's leading political grievance factors such as the weak economy or poverty. This implies that the project not only enormously changes the Ethiopian polity's domestic political settings, but it also introduces new relation in the Nile Basin Region.

Accordingly, substantial, and inclusive developmental changes reduce exploiting ethnicity as a means of political mobilization to achieve a political end. In this sense, the GERD's economic and political impacts could covertly or overtly help regulate ethnic extremism and its narratives. In Ethiopia, the realization of internal political consensus requires a swift remedial mechanism. Accordingly, the drawn antithetical ethnic demarcations and occasionally fabricated historical narratives have undeniably pushed politics into unfavourable conditions. That is why developmental projects relevant to foster the national sentiment, such as the GERD, could have inimitable economic, political, and cultural relevance to reshape the state's political spectrum at large.

\section{REFERENCES}

Abbay, A. (2004). Diversity and state-building in Ethiopia. African Affairs, 103(413), 593-614. https://doi.org/10.1093/afraf/adh043

Abbink, J. (2011). Ethnic-based federalism and ethnicity in Ethiopia: reassessing the experiment after 20 years. Journal of Eastern African Studies, 5(4), 596-618.

Abdelhadi, M. (2020, 30 Jul.). Egypt fumes as Ethiopia celebrates over Nile dam. BBC News. [online] https://www.bbc.com/news/world-africa-53573154.

Abdelhady, D. and et.al (2015). The Nile and the Grand Ethiopian Renaissance Dam: Is There a Meeting Point between Nationalism and Hydrosolidarity? Journal of Contemporary Water Research \& Education, 155 (1), 73-82. https://doi.org/10.1111/j.1936-704x.2015.03197.x

Abtew, W. and Dessu, S.B. (2019). The Grand Ethiopian Renaissance Dam on the Blue Nile. Springer Geography. Cham: Springer International Publishing. https://link.springer.com/book/10.1007\%2F978-3-319-97094-3.

Alem, H. (2005). Multiethnic Federalism in Ethiopia: a Study of the Secession Clause in the Constitution. Publius: The Journal of Federalism, 35(2), pp.313-335. https://doi.org/10.1093/publius/pji016

Abiy, A. (2020). Responses by Prime Minister Abiy Ahmed to Questions Raised by the House of People's Representatives on Law Enforcement operations in Tigray, Addis Ababa.

Aljazeera News (2020, 10 June). Ethiopian Parliament Allows PM Abiy to Stay in Office Beyond Term. Aljazeera News. https://www.aljazeera.com/news/2020/6/10/ethiopianparliam ent-allows-pm abiy-to-stay-in-office-beyond-term.

Amnesty International (2020). Ethiopia: Investigation Reveals Evidence That Scores of Civilians Were Killed in Massacre in

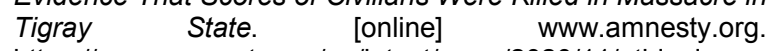
https://www.amnesty.org/en/latest/news/2020/11/ethiopiainvestigation-reveals evidence-that-scores-of-civilians-werekilled-in-massacre-in-tigray-state/ [Accessed 11 Jan. 2021].

Anderson, B. (2006). Imagined Communities Reflections on the Origin and Spread of Nationalism. London and New York: Verso. 
Beker, A. (2016, 2 June). Ethiopia Aims to Lift Itself Out of Poverty by Damming the Blue Nile. Time. https://time.com/4354767/ethiopia-blue-nile-dam/.

BBC. (2021, June 14). Ethiopia's election 2021: A quick guide. BBC News. https://www.bbc.com/news/world-africa$\underline{57102189}$

Carr, C.J. (2017). River Basin Development and Human Rights in Eastern Africa - A Policy Crossroads. Google Books, Springer, p.27.

https://books.google.it/books/about/River Basin_Development_and_Human_Rights.html

Cerutti, F. (2017). Conceptualizing Politics: An Introduction to Political Philosophy. London and New York: Taylor \& Francis.

CGTN Africa. (2020). Ethiopia's Tigray Region Eyes Election in Challenge to National Unity. CGTN Africa. https://africa.cgtn.com/2020/05/07/ethiopias-tigray-region-eyeselection-in-challengeto-nationalunityl [Accessed 9 Aug. 2020].

Gedifew, B. T. (2020). Self-Other Dialectic, Hegel, and the Contemporary Theory of "the politics of Recognition" Skhid, 5(169), https://doi.org/10.21847/1728-9343.2020.5(169).211583

Egypt Independent. (2021). GERD Construction Work Now 79\% Complete, Filling to Go as Scheduled: Ethiopian Minister. Egypt Independent. [Online] 7 May 2021. https://www.egyptindependent.com/gerd-construction-worknow-79-complete-filling-to-go-as-scheduled-ethiopianminister/[Accessed 12 April 2020].

Fukuyama, F. (2018, August 14). Against identity politics. Foreign Affairs. https://www.foreignaffairs.com/articles/americas/2018-08-14/against-identity-politics-tribalism-francisfukuyama

Habitat for Humanity (2021). Ethiopia. https://www.habitat.org/where-we-build/ethiopia [Accessed 6 Apr. 2021.

Human Rights Watch (2019). Ethiopia: Events of 2018. https://www.hrw.org/world-report/2019/country-chapters/ethiopia.

Itao, A. (2010). Paul Ricoeur's Hermeneutics of Symbols: A Critical Dialectic of Suspicion and Faith. Citeseerx.ist.psu.edu.https://citeseerx.ist.psu.edu/viewdoc/do wnload?doi=10.1.1.662.486\&rep=rep1\&type=pdf

International Crisis Group (2020). Nile Dam Talks: Unlocking a Dangerous Stalemate. Crisis Group. https://www.crisisgroup.org/africa/hornafrica/ethiopia/niledam-

talksunlockingdangerous-stalemate [Accessed 9 August 2020].

International Hydropower Association (2020). Ethiopia. https://www.hydropower.org/country-profiles/ethiopia [Accessed 11 Jan. 2021]

International Organization for Migration (2020). Ethiopia Crisis Response Plan 2020 Global Crisis Response Platform. crisisresponse.iom.int.

https://crisisresponse.iom.int/response/ethiopia-crisis-response-plan-2020 [Accessed 11 Jan. 2021].

Joireman, S.F. (2003). Nationalism and Political Identity. London and New York: Continuum.

Kaika, M. (2006). Dams as symbols of modernization: The urbanization of nature between geographical imagination and materiality. Annals of the Association of American Geographers, 96(2), 276-301. https://doi.org/10.1111/j.14678306.2006.00478.x

King, A. and Block, P. (2014). An Assessment of Reservoir Filling Policies for the Grand Ethiopian Renaissance Dam. Journal of Water and Climate Change 5 (2), 233-243. https://doi.org/10.2166/wcc.2014.043

Lyons, T. (2019). The Puzzles of Ethiopian Politics. London: Lynne Reinner Publishers.
Malley, R. (2020). 10 Conflicts to Watch in 2021. Crisis Group. https://www.crisisgroup.org/global/10-conflicts-watch-2021 [Accessed January 13 2021]

Marks, S. and Dahir, A. (2020, 10 Sept.). Ethiopian Region Holds Local Elections in Defiance of Prime Minister. The New York Times. https://www.nytimes.com/2020/09/10/world/africa/ethiopia-tigray-elections-abiy-crisis.html

Melesse, K. (2020. 19 November). Tigray's War Against Ethiopia Isn't About Autonomy. It's About Economic Power. Foreign Policy. https://foreignpolicy.com/2020/11/19/tigray-tplf-war-againstethiopia-abiy-ahmed-isnt-about-autonomy-its-abouteconomic-power/

Menga, F. (2015). Building a nation through a dam: The case of Rogun in Tajikistan. Nationalities Papers, 43(3), 479-494. https://doi.org/10.1080/00905992.2014.924489

Menga, F. (2017). Hydropolis: Reinterpreting The Polis In Water Politics. Political Geography, 60 (September). pp. 100-109. DOI: https://doi.org/10.1016/j.polgeo.2017.05.002

Messay, K. (2020). From Nation-Building to Ethnonations: Ethiopia's Backward Moving History. The World News. [online] 21 July. Available at: https://theworldnews.net/etnews/fromnation-building-to-ethnonations-ethiopia-s-backward-movinghistory [Accessed 12 January 2021]

Palmer, R. P. (2007). The Gadamer Reader: A Bouquet of the Later Writings Evanston, Illinois: Northwestern University Press.

Sky news (2020). At Least 54 Killed in School Field Massacre in Ethiopia, Says Amnesty International. Sky News. [online] 02 Nov. Available at: https://news.sky.com/story/atleast-54killed-in-school-field-massacre-in-ethiopia-says-amnestyinternational12122258 [Accessed 11 Jan. 2021].

Swain, A. (1997). Ethiopia, the Sudan, and Egypt: the Nile River dispute. The Journal of Modern African Studies, 35(4), 675694.

The Guardian (2020, 23 December). At Least 102 Killed in Massacre in Western Ethiopia After Abiy Visit. The Guardian. https://www.theguardian.com/world/2020/dec/23/at-least102-killed-in-massacre-inwestern-ethiopia-after-abiy-visit [Accessed 11 Jan. 2021].

UNHCR (2020). Ethiopia Tigray Emergency. [online] UNHCR. https://www.unhcr.org/ethiopia-tigray-emergency.html [Accessed January 16 2021].

United Nations Office for Humanitarian Affairs (2018). Ethiopia: Oromia - Somali Conflict Induced Displacement. https://reliefweb.int/report/ethiopia/ethiopia-oromia-somaliconflict- induced displacement-situation-report-no-4-20-june [Accessed 11 Jan. 2021].

Wilson, T. (2019, 30 May). Ethnic Violence in Ethiopia Has Forced Nearly 3 Million People from Their Homes. Los Angeles Times. https://www.latimes.com/world/la-fg-ethiopiaethnic-violencemillions displaced20190530-story.html.

World Bank (2019). World Bank Open Data | Data. data.worldbank.org. https://data.worldbank.org/.

World Bank (2020). World Bank Open Data | Data. [online] Worldbank.org. https://data.worldbank.org/.

World Population Review (2020). 2020 World Population by Country. [online] Worldpopulationreview.com. https://worldpopulationreview.com/.

World Population Review. (2021). Ethiopia population 2020. https://worldpopulationreview.com/countries/ethiopiapopulation

Yihdego, Y., Khalil, A., and Salem, H.S. (2017). Nile River's Basi n Dispute: Perspectives of the

Grand Ethiopian Renaissance Dam (GERD). Global Journal of Human-Social Science: B Geography, Geo-Sciences, Environmental Science \& Disaster Management, [online] 17(2), https://www.researchgate.net/publication/317372179 
Андебет Хайлу Асефа,

Школа новітніх досліджень Сант Анна (Піза, Італія)

e-mail: andebethailu.assefa@santannapisa.it, ORCID 0000-0001-8698-2364

Белайне Тайе Гедифев,

Сегедський університет (Сегед, Угорщина)

e-mail: belayneh3415@gmail.com,ORCID0000-0003-1629-136X

\section{СИМВОЛІЧНІ ЦІННОСТІ ТА НАСЛІДКИ ПРОЕКТУ ГРЕБЛІ ВЕЛИКОГО ВІДРОДЖЕННЯ ЕФІОПIÏ В ПОЛІТИЦІ ЕФІОПСЬКОї ІДЕНТИЧНОСТІ}

Стаття присвячена аналізу ідентифікаційних процесів, що відбуваються в сучасній Ефіопії під впливом модернізаційних змін. Зокрема описується - як економічні та політичні здобутки сприяють спільному пог-ляду на майбутнє з боку протилежних один одному етноцентричного та пан-ефіопського націоналістичного таборів. Наразі в ефіопській політиці домінують різні етнічні "протигрупові" та "позагрупові" політичні дискурси. У статті розглядаються та висвітлюються відповідні філософські концепції, включаючи "дзеркальну ідентичність", первісну та інструментальну концепцію етнічної приналежності. Примітно, що, дотримуючись напряму думок Б. Андерсона про націоналізм як "культурний артефакт" та вираз "уявної спільноти", автори доходять висновку, що GERD може слугувати спільною символічною мовою та мовою розвитку, щоб змінити ефіопську національну свідомість та уяву, покращуючи політичні та економічні сфери країни. Реалізація проекту греблі Великого Відродження Ефіопії (GERD) приховано чи відверто допомагає реформувати механізми самовизнання державної влади та поступово реагує на видатні політичні розбіжності, вибудовуючи відносини на основі довіри серед основних політичних акторів. Етноцентричні мотивації порушують такі політичні питання, як сецесія, право на мовне та культурне визнання, економічна рівність та політична безпека та представництво шляхом використання їх відповідних етнічних приналежностей як засобу політичної мобілізації. у нинішній Ефіопії політична ідентичність практично поєднується з етнічною ідентичністю. У цьому сенсі, оскільки існують різноманітні етнічні групи, політичні кордони підтримуються серед численних націоналістів, що базуються на етнічній основі, та між загальноефіопськими та етноцентричними суб'єктами. Отже, необхідний всебічний діалог та конструктивне політичне взаємне запліднення між різними політичними суб'єктами, горизонтально та вертикально, між етноцентричними націоналістами та загальноефіопськими захисниками. В Ефіопії реалізація внутрішньополітичного консенсусу вимагає миттєвого механізму корекції. Відповідно, політично заангажовані антитетичні етнічні розмежування та періодично сорабриковані історичні наративи, спричинили несприятливі умови в політиці. Ось чому, як визначають автори статті, такі проекти розвитку, як GERD, мали б відповідні економічні та політичні механізми для розвитку національних настроїв, що, в свою чергу, символічно сприятиме національному консенсусу серед основних політичних суб'єктів. Отже, запозичивши поняття Ф.Фукуями про "національну ідентичність віросповідання", можна було б резюмувати, що ці проекти розвитку можуть допомогти реалізувати символічну цінність, конструктивно надавши громадянам змогу визнати основоположні ідеали своїх країн та піднявши загальні фактори. Перспективами продовження даного дослідження є вплив зовнішніх геополітичних та правових чинників на проект GERD.

Ключові слова: етнічна приналежність, Ефіопія, етнічний федералізм, GERD, мова розвитку, політика ідентичності.

(C) Andebet Hailu Assefa, Belayneh Taye Gedifew

Надійшла до редакції: 04.04.2021

Прийнята до друку: 02.06.2021 